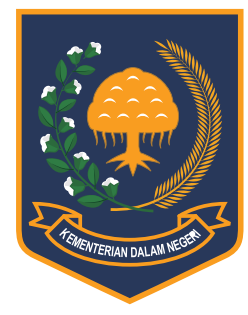

Jurnal Bina Praja 10 (1) (2018): 13-26

Jurnal Bina Praja

e-ISSN: 2503-3360 | p-ISSN: 2085-4323

Accreditation Number

735/AU2/P2MI-LIPI/04/2016

http://jurnal.kemendagri.go.id/index.php/jbp/index

\title{
READINESS ANALYSIS \\ OF REGIONAL INNOVATION IMPLEMENTATION
}

\author{
Sitti Aminah*, Dyah Kusuma Wardani \\ Research and Development Agency, \\ Ministry of Home Affairs, Republic of Indonesia \\ Jalan Kramat Raya No. 132, Senen, Central Jakarta
}

Received: 6 February 2018 ; Accepted: 22 March 2018; Published online: 12 May 2018

DOI: $10.21787 / j b p .10 .2018 .13-26$

\begin{abstract}
The implementation of regional innovation has not been effective in improving public services and regional competitiveness. Several factors are considered to be an obstacle to implementing regional innovation, namely regulation, institutions, culture and leadership. The purpose of this study is to analyze the readiness of innovation support factors and also to analyze the relationship between these factors in the implementation of regional innovation. Data were collected by interviews and questionnaires distributed in July, August, and September 2016 in 7 (seven) Districts selected to represent HDI High areas, such as Palembang, Surakarta, Bandung and Batam and also represented Low HDI areas: Pesawaran, Bangkalan, and West Lombok. Data were analyzed by descriptive statistic and Pearson Correlation with SPSS ver.16 program. The results showed that the readiness of factors of factorization interpretation, regulatory readiness, leadership, innovation culture, and facilities and infrastructure were in high category, while the preparedness factor from the coordination and facilitation faced by stakeholders was also low category cooperation. The results show that all the factors supporting innovation except for facilitation and coordination in high HDI areas are superior to low HDI areas. The relationship between the supporting factors reveals that there are three types of relationships: very important, important, and not very important. Local innovation development strategies consist of core strategies and support strategies.
\end{abstract}

Keywords: Innovation, Regional Innovation, Readiness

\section{INTRODUCTION}

Innovation has become one of the key factors to state's economy development and prosperity (James, 2010; United Nations Conference on Trade and Development, 2010). Innovation is used as a key element to state's competitiveness index, both as the main elements such as Global Innovation Index (GII) as well as an additional element such as Human Development Index. A country that does not innovate will lag behind other countries (Lembaga Administrasi Negara, 2016). As we can see from both of these aspects, the development of innovation and competitiveness in Indonesia does not meet the expectation, according to Global Innovation Index (2016) Indonesia's innovation position is ranked 88th out of 128 countries. While the position of competitiveness in 2016 according to data Competitiveness Global Index (2016) is ranked 41, lagging behind Singapore at 2nd position, Malaysia, and Thailand at rank 25 and 34 respectively. Meanwhile, the range of HDI achievement in District/Town is between 60 to 69, whereas 80 is the ideal HDI of a region according to the World Bank.

In public sector, public service innovation has not yet satisfied public trust. The result of Tempo and AusAID survey in 2014 revealed that public satisfaction perception to public services was relatively low especially in the aspect of service quality, accountability of bureaucracy performance and business licensing permits convenience each at 18 percent, 13 percent and 24 percent respectively (Imanudin, 2016). Public satisfaction to public service provided by the government has an impact on the legitimacy of power, especially in the era of

\footnotetext{
* Corresponding Author

Phone : +62821 13160178

Email : sittiaminah.kemendagri@gmail.com
} 


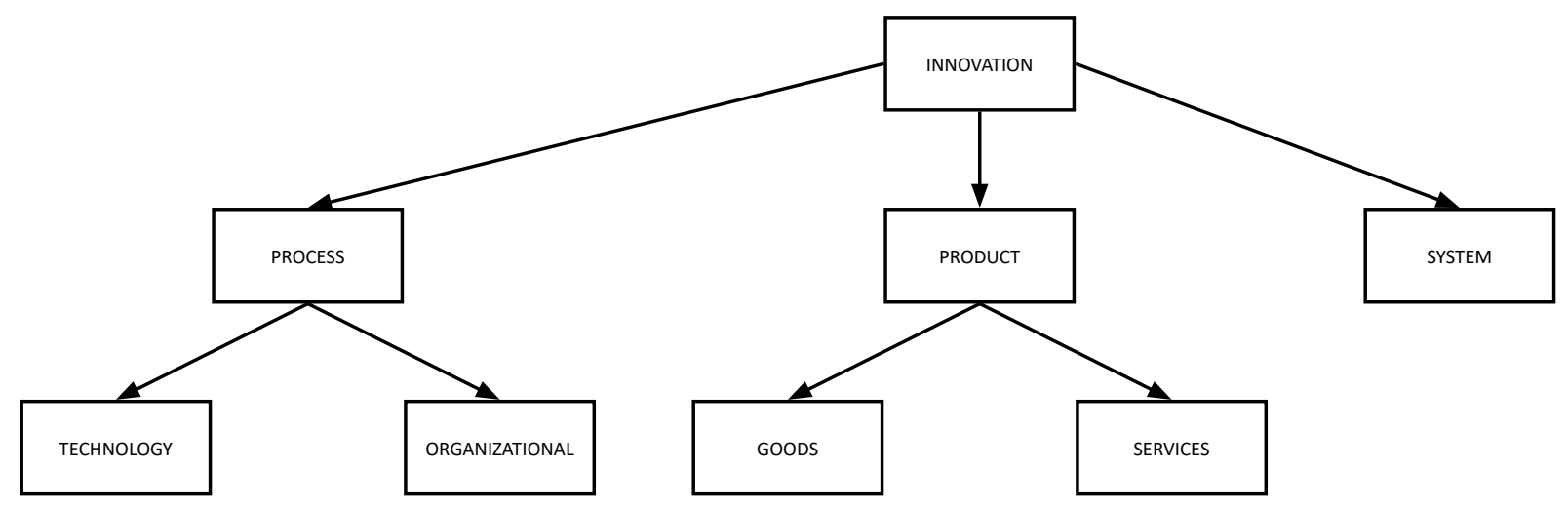

Figure 1. Innovation Taxonomy

Source: Edquist (2001; 2008)

direct regional election (Dwiyanto, 2015). In line with this opinion, Pramusinto (2016) said public distrust to the government in providing satisfactory public services is harmful to the legitimacy of government.

This becomes the challenge of Central and Local government to innovate in order to overcome various regional issues. Regional innovation is regulated by Law Number 23 of 2014 on articles 386 to 390 mandated the Regional government to implement innovation in governance. However, judging from quantity aspect that is the amount and the quality of regional innovation that benefit the society, not all areas are capable of implementing Regional Government mapping that implements public service innovation on year 2014, 2015, and 2016 mostly spread to western region ( Java and Sumatera), a small part of Kalimantan and Sulawesi, a few areas in Eastern Region such as Maluku, meanwhile Papua and Nusa Tenggara are poor at innovation (Natalisa, 2016).

Based on the description above, the purpose of this study is to analyze the level of preparedness of local governments to innovate in high and low HDI areas by analyzing various factors such as understanding to innovation, regulation readiness, leadership, innovation culture, coordination and facilitation, the role of stakeholders and infrastructures. Furthermore, this study analyzes the relation between factors and composing the direction of policy and local development program.

Various innovation concept and supporting factors to the development of regional innovation become the reference to this study. Many experts have defined innovation, among them is Rogers (2003) who defines innovation as an idea, action, or practice that is considered new by a person or audiences. The World Bank (2007) defines innovation as the idea to a process of local change-making, something new to the user where innovation process is based on, especially the process where the organization controls and executes the design and production of new goods and services for themselves, competitors, as well as for the world. Furthermore, Law Number 23 of 2014 defines innovation as all forms of renewal in local governance. Referring to the definition of innovation, it appears that the main characteristic of innovation is the novelty. Thus, innovation is defined as new ideas, actions or practices undertaken by local governments to create change and added value in products, goods, and services in order to improve people's lives. New ways are created to promote competitiveness and public services also to address problems in the region.

Innovation, according to Edquist taxonomy (2001; 2008) consists of processes, products, and systems (Figure 1). Innovation as a "process" and/ or "outcome" of the development and/or utilization of knowledge, skills (including technological skills) and experience to create (repair) new products (goods and/or services), processes and/or systems that provide significant (especially economic and social) value.

In the public sector, Ancok (2012) suggests 8 (eight) types of innovation in the government sector, namely: (1) Innovation process as a simplification of work processes; (2) Innovation Method as a new way of conducting government activities; (3) Innovation organizational structure is the adoption of a new organizational model to replace the old, rigid, hierarchical, and fragmented model; (4) Innovation in relationships is innovation in relationships with outside parties such as customers and suppliers, by involving them to be part of organizational activities; (5) Innovation strategy as a change in plans in order to achieve certain goals and replacing the less beneficial old plan; (6) Innovation mindset; innovation that changes the perspective in facing a problem; (7) Product innovation to produce new products by improving quality, function, and image; 
(8) Service innovation is a change in the provision of services to customer satisfaction.

According to Mulgan \& Albury (2003), any type of innovation in the government sector can be applied if the Government understands the following inhibiting factors: (1) Reluctance to close down the failing program or organization. Leaders or parties who refuse to stop the program or dismiss the organization that has failed; (2) Over-reliance on high performers as the source of innovation. Innovation is driven by strong and consistent figures; (3) Technologies available but constraining cultural or organizational arrangement. The barriers to innovation are not due to the unavailability of technology, but because of a culture or organizational policy that is not pro-innovation; (4) No rewards or incentives to innovate or adopt innovations. Lack of appreciation to encourage and motivate the employee to make changes; (5) Poor skills in active risk or change management. Weak skills to deal with risks or to manage changes; (6) Shortterm budget and planning horizons. Limited budget allocation support and short-term budget planning will hamper the sustainability of innovation; (7) Delivery pressures and administrative burdens. Public service demands are often confronted with administrative burdens; (8) The culture of risk aversion. Unwillingness in facing risks as a psychological and cultural constraint.

Inhibiting factors of government innovation in the public sector are documented in several kinds of literature: lack of leadership at each level of the organization, lack of coordination, limited resources and budget as well as knowledge. Addressing these barriers will make innovation more readily available in the public sector (European Commission, 2013). In Indonesia, the inhibiting factors have caused the government to be less ready to innovate. Based on the study of Java Post Institute of Pro-Autonomy (JPIP) Year 2014, those inhibiting factors are (1) Poor management innovation, (2) Decreasing of SKPD enthusiasm in implementing innovation, (3) Central regulation barriers and (5) Leadership changes. The success of innovation can be determined by the strong commitment of the head of the region, the high response of the community, stable bureaucracy and appreciation.

According to Taufik (2005), there are factors that encourage the government to be ready to innovate: (1) Conducive policies and regulations; (2) The supporting capacity of institutional, scientific and technological resources and innovation, as well as the improvement of business capability utilizing science and technology and innovation; (3) The partnership between parties and the utilization of science and technology and innovation in government institutions, business, and society); (4) The culture of innovation; (5) Policy coherence; (5)
Ability to face global challenges. Besides these five factors, Sumarto (2009) emphasized the importance of the role of leaders and the role of central and local government in coordinating and facilitating regional innovation. According to him, one of the missing components at unsuccessful areas is the presence of innovative leaders. Many government leaders are still doing the principal of business as usual, where they apply old values and tend not to take risks. As the push for changes is getting stronger, it is necessary to have leaders who implement innovation seriously. On the other hand, regional innovation is underdeveloped due to the weak role of government in coordinating and facilitating the formation of various mechanisms to encourage regional innovation through capacity building in the form of learning facilitating, encouraging creativity and initiative as well as budget preparation to fund innovative programs or innovation infrastructure assistance.

The role of the government to develop innovation will be imbalanced if they do not build partnerships with stakeholders i.e. academics as a provider of technological innovation, businesses act as producers meanwhile marketers and the Government as regulators. Although they have their respective roles, they can at the same time benefit from the role of other institutions, for example, the government uses the services of universities to conduct studies on how to improve local competitiveness. Civil society is included so that citizens' voices can be represented and development becomes more human-sensitive. Regional innovations require stakeholders to work together (Carayannis, Barth, \& Campbell, 2012; Dell'Anno \& del Giudice, 2015; Etzkowitz \& Ranga, 2010; Kimatu, 2016). Saparita's findings (2015) reveal that the weak role of stakeholders in the development of innovation systems has an impact on the slow poverty reduction in Belu Regency, NTT Province. Local governments have not reached the optimum level in establishing a cooperative network between business actors for agricultural products marketing and universities and R \& D institutions to develop innovations that farmers need. This causes farmers to fail to improve the marketing and production of agricultural products. Thus, it makes poverty difficult to overcome.

Innovation also requires the readiness of infrastructure. As an example is the success of SIDa Semarang city because of the availability of (1) Information communication technology (ICT) including information and communication support, ICT quality and range. (2) Availability of work training facilities, research laboratories and their effectiveness and (3) Availability of accessible financial institutions (Saparita et al., 2015) 
Several previous studies relevant to this study were conducted by Handayani, Setyono, Sophianingrum, \& Kusharsanto (2012) who examines the readiness of the development of regional innovation system (SIDa) in Semarang City on 3 (three) factors namely the role of stakeholders, infrastructure and policy support. The strength of this study lies in the completeness of the secular data as an analytical base, however, it only examines these three aspects even though the role and commitment of leaders for SIDa development are essential. Handayani, Sophianingrum \& Nutriandini (2013) examines the development of Regional Innovation System (SIDa) in Semarang City by analyzing these factors: policy and regulation, innovation infrastructure, institutional science and technology capacity, innovation culture and industrial cluster development. The strength of this study lies on the variables to analyze development readiness SIDa with secondary data support. But it has not yet examined the role of government in building synergies between science and technology institutions and leadership commitment to ensure the continuation of innovation development through SIDa. Main Study (2013: 24-30) examines the readiness of Central and Local Governments to implement policy innovations on adaptation and mitigation aspects of climate protection. Furthermore, Purnomo, Pujianto \& Efendi (2015) examines the implementation of Triple Helix collaboration model for SME development by the Majalengka Regency government. Both studies only focus on specific aspects such as government's readiness to implement policy and stakeholder role models.

The advantages of this study from previous studies are seen from several aspects that become the determinants of the success of regional innovation but have not been studied by previous researchers, namely: aspects of leadership, innovation culture and the role of government in carrying out coordination and facilitation functions. In contrast to previous studies using qualitative methods, this study used a quantitative method supported by qualitative explanations. Furthermore, site selection was done based on the achievement of the high and low Human Development Index (HDI) to see the variety of data on the readiness of the implementation of innovation in the developed and developing areas at which this study is located.

Based on the opinion of Mulgan \& Albury (2003), European Commission (2013), and Taufik (2005) including previous researches conducted by previous researchers who revealed factors related to public sector innovation readiness, this study identifies factors related to innovation readiness in local government organizations, including: (1) understanding of innovation; (2) regulatory readiness; (3) innovative leadership; (4) culture innovation; (5) coordination and facilitation; (6) stakeholder cooperation; and (7) readiness of infrastructure.

\section{METHOD}

The study used a quantitative approach to analyze the primary data obtained from the questionnaire. The quantitative approach is strengthened by an explanation of qualitative data from in-depth interviews and observations. Site selection was done by looking at Human Development Index (HDI) in High and Low categories based on BPS 2014 criteria. Although HDI does not comprehensively indicate the level of regional progress by seeing from the achievement of the living standard of society on the aspect of life expectancy, achievement literacy rate and education and a decent standard of living. Location selection was justified based on HDI to see the variation of data achievement of the readiness implementation of regional innovation in the study location area where the community is classified as developed and developing. This is government intervention basis to structuring determinant factors to drive successful implementation of regional innovation in both types of regions (developed and developing regions).

Data were collected in July to September 2016 in 7 (seven) districts representing the high HDI areas of Palembang, Surakarta, Bandung and Batam and low HDI areas of Pesawaran, Bangkalan and West Lombok (Table 1).

Research population in this study is local governments in high and low HDI area. Local organizations (OPDs) from the government that actively innovate in high and low HDI areas. The sampling technique used in this study is purposive sampling. Purposive sampling was done by taking respondents of echelon 2 and 3 officials at local organizations (OPD) who are directly and actively involved in the innovation implementation as their main task and function. Out of 56 sample target

Table 1.

Study Location

\begin{tabular}{clcl} 
& High HDI & & Low HDI \\
\hline 1 & $\begin{array}{l}\text { Palembang City } \\
(76.02)\end{array}$ & 1 & $\begin{array}{l}\text { Pesawaran Ditrict } \\
(61.70)\end{array}$ \\
\hline 2 & $\begin{array}{l}\text { Surakarta City } \\
(79.34)\end{array}$ & 2 & $\begin{array}{l}\text { Bangkalan District } \\
(60.71)\end{array}$ \\
\hline 3 & $\begin{array}{l}\text { Bandung City } \\
(69.06)\end{array}$ & 3 & $\begin{array}{l}\text { Lombok Barat } \\
\text { District (63.2) }\end{array}$ \\
\hline 4 & Batam City (79.13) & & \\
\hline
\end{tabular}


Table 2.

Respondent Sample

\begin{tabular}{|c|c|c|c|c|c|}
\hline No & $\begin{array}{l}\text { Typology of } \\
\text { Region }\end{array}$ & District/City & $\begin{array}{c}\text { Selected Local } \\
\text { Organization (OPD) }\end{array}$ & $\begin{array}{c}\text { Target } \\
\text { Respondent }\end{array}$ & Respondent \\
\hline 1 & High HDI & $\begin{array}{l}\text { 1. Palembang City } \\
\text { 2. Surakarta City } \\
\text { 3. Bandung City } \\
\text { 4. Batam City }\end{array}$ & \multirow{2}{*}{$\begin{array}{l}\text { Balitbang, Bappeda, } \\
\text { Disperindag, PMPK-UKM, } \\
\text { Community Empowerment } \\
\text { Board, Education Agency and } \\
\text { civil registration, Public Work } \\
\text { Agency, PTSP - Tax Service } \\
\text { Office. }\end{array}$} & 32 & 22 \\
\hline 2 & $\begin{array}{l}\text { Medium-Low } \\
\text { HDI }\end{array}$ & $\begin{array}{l}\text { 1. Pesawaran District } \\
\text { 2. Bangkalan District } \\
\text { 3. West Lombok }\end{array}$ & & 24 & 16 \\
\hline \multicolumn{5}{|c|}{ Total Respondents } & 38 \\
\hline
\end{tabular}

respondents, only 38 were filled out and returned the questionnaire (Table 2).

Prior to the survey validity and reliability tests were performed with the results presented in Table 3.

Data were analyzed using descriptive statistics, differential test ( $t$-test) and Pearson correlation. To test statistically, it is necessary to transform the variables so that all collected data have the same range, i.e. 0 - 100 (Sumardjo, 1999).

$\underline{\text { Number of scores achieved }- \text { The number of expected minimum scores }} \times 100$ Maximum number of expected scores - expected minimum score

Note: Range value of the variable index $0-100$

Measurement of indicators uses the scale parameter 1-4 so that the minimum transformation index value (0) is achieved when all parameters of each measured indicator are 1 . While the maximum value (100) is achieved when all parameters of each indicator are 4, so the data distribution is an interval scale with a value ranging from $0-100$. The categorization is divided into four levels: 0-25 "very low", 26-50 "low", 51-75 "medium" and 76-100 "high"

The $t$-test is used to distinguish two mean samples with the following formula:

$$
t=\frac{\left|\bar{X}_{1}-\bar{X}_{2}\right|}{S_{x 1-x 2}}
$$

$$
\begin{array}{ll}
\text { Notes: } & \\
\bar{X}_{1} & =\text { statistic value }(\text { t count }) \\
\bar{X}_{2} & =\text { Mean from sample } 1 \text { observation } \\
S_{x 1-x 2} & =\text { Mean from sample } 2 \text { observation }
\end{array}
$$

Furthermore, to analyze the relationship between variables this study used Pearson Correlation with SPSS program version 16. This correlation explains the relationship between

Table 3.

Validity and Reliability Test Result

\begin{tabular}{lll}
\multicolumn{1}{c}{ Variables } & \multicolumn{1}{c}{$\begin{array}{c}\text { Approximate Validity Value } \\
\text { (Coefficient } r \text { ) }\end{array}$} & Approximate Reliability Value \\
\hline Innovation Perception (X1) & $0.462-0.798$ & $0.905-0.919$ \\
\hline Regulation Readiness (X2) & $0.426-0.774$ & $0.906-0.919$ \\
\hline Innovative Leadership (X3) & $0.388-0.861$ & $0.885-0.896$ \\
\hline Innovation Culture (X4) & $0.656-0.850$ & $0.884-0.897$ \\
\hline Coordination and Facilitation (X5) & $0.526-0.904$ & $0.884-0.896$ \\
\hline Stakeholder Roles (X6) & $0.601-0.904$ & $0.884-0.890$ \\
\hline Infrastructure Readiness (X7) & $0.850-0.865$ & $0.882-0.906$
\end{tabular}


Table 4.

Aspects of Study

\begin{tabular}{|c|c|c|c|}
\hline No & Aspect & Study Limitation & Sub Element \\
\hline $\mathrm{X} 1$ & $\begin{array}{l}\text { Understanding of regional } \\
\text { innovation }\end{array}$ & $\begin{array}{l}\text { The objectives of the study are limited } \\
\text { to local officer understanding of regional } \\
\text { innovation and the dissemination of } \\
\text { innovation information to employees and } \\
\text { stakeholders (Academics, business actors, } \\
\text { and communities). }\end{array}$ & $\begin{array}{l}\text { 1. Understanding level of regional innovation } \\
\text { 2. The level of information dissemination to } \\
\text { employees and stakeholders. }\end{array}$ \\
\hline $\mathrm{X} 2$ & $\begin{array}{l}\text { The readiness of regulation } \\
\text { and policy }\end{array}$ & $\begin{array}{l}\text { The object of study is limited to regulations } \\
\text { and policies that support the implementation } \\
\text { of innovation, consistency of planning and } \\
\text { regional innovation supporting policy. }\end{array}$ & $\begin{array}{l}\text { 1. Availability of regulation } \\
\text { 2. Planning consistency } \\
\text { 3. The readiness of supporting policy } \\
\text { (education, poverty mitigation, } \\
\text { investment, incentive/people's credit. }\end{array}$ \\
\hline $\mathrm{X} 3$ & Innovative leadership & $\begin{array}{l}\text { The object of study is limited to the role of } \\
\text { the leader in making changes and keeping the } \\
\text { sustainability of innovation. }\end{array}$ & $\begin{array}{l}\text { 1. Leader's commitment } \\
\text { 2. The consistency of innovation despite } \\
\text { leadership change. }\end{array}$ \\
\hline $\mathrm{X} 4$ & Innovation Culture & $\begin{array}{l}\text { The object of study.is limited to } \\
\text { organizational culture for innovation. }\end{array}$ & $\begin{array}{l}\text { 1. Employee's enthusiasm in giving new idea } \\
\text { input } \\
\text { 2. Appreciation (incentive). }\end{array}$ \\
\hline X5 & $\begin{array}{l}\text { Level of Coordination and } \\
\text { Facilitation }\end{array}$ & $\begin{array}{l}\text { The object of study is limited to central } \\
\text { government support and how local } \\
\text { government coordinates and facilitates } \\
\text { innovation. }\end{array}$ & $\begin{array}{l}\text { 1. Coordination intensity among central } \\
\text { government } \\
\text { 2. Coordination intensity among local } \\
\text { government } \\
\text { 3. Facilitation intensity(Budget, human } \\
\text { resources and equipment/technology). }\end{array}$ \\
\hline$x 6$ & $\begin{array}{l}\text { Cooperation among } \\
\text { stakeholders (government, } \\
\text { universities, business actors) }\end{array}$ & $\begin{array}{l}\text { The object of study is limited to cooperation } \\
\text { among stakeholders in supporting innovation. }\end{array}$ & $\begin{array}{l}\text { 1. Coordination intensity among universities } \\
\text { 2. Coordination intensity among business } \\
\text { actors } \\
\text { 3. Community participation and cooperation. }\end{array}$ \\
\hline $\mathrm{X7}$ & Infrastructures & $\begin{array}{l}\text { The object of study is limited to availability } \\
\text { level of infrastructures to regional innovation. }\end{array}$ & $\begin{array}{l}\text { ICT support, training facilities, financial } \\
\text { institutions, markets and transportation } \\
\text { facilities, market laboratories, communication } \\
\text { media and information facilities. }\end{array}$ \\
\hline
\end{tabular}

indicators that characterize each variable. The result of the analysis becomes the material to formulate the direction and implementation policy of regional innovation.

Analysis of the supporting factors to the readiness of innovation based on the perception of local organizations from 8 aspects. (Table 4).

\section{RESULTS AND DiSCUSSION}

\section{A. Readiness Level of Regional Innovation Supporting Factors}

The level of preparedness of regional innovation supporting factors in high HDI and low HDI areas is relatively high in the factors of understanding of innovation, regulatory readiness, innovative leadership, innovation culture and the readiness infrastructure, with an average score of $64,71,63$, 54 and 65 . However, coordination and facilitation factors are low with scores that fall in the range of 40 and 48 (see Table 5). This shows that the facilitation and coordination, as well as the cooperation among stakeholders who is supposed be the responsibility of Local Government, has become an obstacle to the implementation of regional innovation. One of the causes of low levels of facilitation and coordination is the control gap between government level and the inactivity of efforts to improve coordination and facilitation in implementing regional innovations. Lack of stakeholder cooperation (Academics, Business Actors, and Communities) is caused by the lack of government efforts in utilizing and integrating university research results.

The differential test results show that except for facilitation and coordination factors, innovation support factors in high HDI areas are far superior to low HDI areas (see Figure 1 spider web diagram), including perceptions of understanding of innovation, regulatory readiness, innovative leadership, innovation culture, roles and stakeholder cooperation and infrastructure readiness. 
Table 5.

Distribution Percentage of Readiness Level of Regional Innovations Supporting Factors

\begin{tabular}{|c|c|c|c|c|c|c|c|c|}
\hline \multirow{2}{*}{ Readiness Factor } & \multirow{2}{*}{ Category } & \multicolumn{2}{|c|}{$\begin{array}{l}\text { High HDI } \\
\quad(n=22)\end{array}$} & \multicolumn{2}{|c|}{$\begin{array}{l}\text { Low HDI } \\
(n=16)\end{array}$} & \multicolumn{2}{|c|}{$\begin{array}{c}\text { Total } \\
(n=38)\end{array}$} & \multirow{2}{*}{$\begin{array}{c}\text { Sig } \\
(U j i t)\end{array}$} \\
\hline & & $\mathbf{n}$ & $\%$ & $\mathbf{n}$ & $\%$ & $\mathbf{N}$ & $\%$ & \\
\hline Regional Innovation & Very Low & 0 & 0 & 0 & 0 & 0 & 0 & 0.005 \\
\hline \multirow[t]{3}{*}{ Understanding } & Low & 4 & 18 & 5 & 31 & 9 & 24 & \\
\hline & High & 12 & 55 & 9 & 56 & 21 & 55 & \\
\hline & Very High & 6 & 27 & 2 & 13 & 8 & 21 & \\
\hline \multicolumn{2}{|l|}{ Mean } & \multicolumn{2}{|c|}{66} & \multicolumn{2}{|c|}{60} & \multicolumn{2}{|c|}{64} & \\
\hline \multirow[t]{4}{*}{ Regulation Readiness } & Very Low & 0 & 0 & 0 & 0 & 0 & 0 & 0.005 \\
\hline & Low & 0 & 0 & 3 & 19 & 3 & 8 & \\
\hline & High & 11 & 50 & 9 & 56 & 20 & 53 & \\
\hline & Very High & 11 & 50 & 4 & 25 & 15 & 39 & \\
\hline \multicolumn{2}{|l|}{ Mean } & \multicolumn{2}{|c|}{75} & \multicolumn{2}{|c|}{64} & \multicolumn{2}{|c|}{71} & \\
\hline \multirow[t]{4}{*}{ Innovative Leadership } & Very Low & 0 & 0 & 0 & 0 & 0 & 0 & 0.031 \\
\hline & Low & 2 & 9 & 4 & 25 & 6 & 16 & \\
\hline & High & 11 & 50 & 12 & 75 & 23 & 61 & \\
\hline & Very High & 9 & 41 & 0 & 0 & 9 & 24 & \\
\hline \multicolumn{2}{|l|}{ Mean } & \multicolumn{2}{|c|}{67} & \multicolumn{2}{|c|}{57} & \multicolumn{2}{|c|}{63} & \\
\hline \multirow[t]{4}{*}{ Innovation Culture } & Very Low & 0 & 0 & 0 & 0 & 0 & 0 & 0.007 \\
\hline & Low & 5 & 23 & 10 & 63 & 15 & 39 & \\
\hline & High & 16 & 72 & 6 & 38 & 22 & 58 & \\
\hline & Very High & 1 & 5 & 0 & 0 & 1 & 3 & \\
\hline \multicolumn{2}{|l|}{ Mean } & \multicolumn{2}{|c|}{58} & \multicolumn{2}{|c|}{48} & \multicolumn{2}{|c|}{54} & \\
\hline Coordination and & Very Low & 7 & 32 & 2 & 13 & 9 & 24 & 0.005 \\
\hline Facilitation & Low & 8 & 36 & 8 & 53 & 16 & 43 & \\
\hline & High & 6 & 27 & 5 & 33 & 11 & 30 & \\
\hline & Very High & 1 & 5 & 0 & 0 & 1 & 3 & \\
\hline Mean & & & & & & & & \\
\hline Stakeholder Roles & Very Low & 0 & 0 & 0 & 0 & 0 & 0 & 0.52 \\
\hline & Low & 15 & 68 & 10 & 63 & 25 & 66 & \\
\hline & High & 6 & 27 & 6 & 38 & 12 & 32 & \\
\hline & Very High & 1 & 5 & 0 & 0 & 1 & 3 & \\
\hline Mean & & & & & & & & \\
\hline Infrastructure & Very Low & 0 & 0 & 0 & 0 & 0 & 0 & 0.005 \\
\hline Readiness & Low & 1 & 5 & 1 & 6 & 2 & 5 & \\
\hline & High & 15 & 68 & 14 & 88 & 29 & 76 & \\
\hline & Very High & 6 & 27 & 1 & 6 & 7 & 18 & \\
\hline Mean & & & & & & & & \\
\hline
\end{tabular}

Note:

$0 \leq 25=$ very low, $26 \leq 50=$ low, $51 \leq 75=$ high, $76-100=$ very high

** very significant at $p<0.01$ and

* significant at $p<0.05$

Understanding of regional innovation is high. The result of a differential test of innovation understanding factor between high and low HDI area shows that there is a significant difference. High HDI areas have higher levels of understanding and implementation of socialization implementation than low HDI areas. This poses a challenge for high HDI areas to improve communication and innovation among employees. 
Table 6.

Readiness Condition of Regional Innovation Supporting Regulations

\begin{tabular}{|c|c|c|c|c|}
\hline No & District/City & Regulation Availability & $\begin{array}{l}\text { Listed/Unlisted } \\
\text { in RPJMD/RKPD }\end{array}$ & Notes \\
\hline 1 & Palembang & $\begin{array}{l}\checkmark \\
\text { Local Regulation and Government } \\
\text { Regulation in investment licensing } \\
\text { services innovation and strategic } \\
\text { infrastructure development. }\end{array}$ & $\checkmark^{*}$ & $\begin{array}{l}\qquad \checkmark^{*} \\
\text { Unlisted in RPJMD, but listed in SKPD } \\
\text { strategic planning }\end{array}$ \\
\hline 2 & Surakarta & $\begin{array}{c}\checkmark \\
\text { Local Innovation Regulation concerning } \\
\text { Solo Technopark development, public } \\
\text { service and licensing }\end{array}$ & $\checkmark$ & \\
\hline 3 & Batam & $\begin{array}{c}\checkmark \\
\text { Local regulations in Public service } \\
\text { innovation, licensing/investment } \\
\text { services, and community } \\
\text { empowerment }\end{array}$ & $\checkmark^{*}$ & $\begin{array}{l}\qquad \checkmark^{*} \\
\text { Unlisted in RPJMD, but listed in SKPD } \\
\text { strategic planning }\end{array}$ \\
\hline 4 & Bandung & $\begin{array}{c}\checkmark \\
\text { Draft of SIDA local regulations and } \\
\text { Urban Innovation regulation (Bandung } \\
\text { SMART City) }\end{array}$ & $\checkmark$ & $\begin{array}{l}\text { Regional Innovation is listed in RPJMD } \\
\text { but only focus on creative economy }\end{array}$ \\
\hline 5 & Pesawaran & $x$ & $x$ & $\begin{array}{l}\qquad \mathbf{V}^{*} \\
\text { Unlisted in RPJMD, but listed in SKPD } \\
\text { strategic planning }\end{array}$ \\
\hline 6 & Lombok Barat & $\stackrel{\checkmark}{\checkmark}$ Local Regulation in service innovation & $\checkmark^{*}$ & $\begin{array}{l}\qquad \mathbf{V}^{*} \\
\text { Unlisted in RPJMD, but listed in SKPD } \\
\text { strategic planning }\end{array}$ \\
\hline 7 & Bangkalan & $x$ & $x$ & \\
\hline
\end{tabular}

Note:

$\mathbf{x}=$ none

$\boldsymbol{V}=$ any

Source: Secondary data process

The readiness on both high and low HDI areas are in high category (score range average 75 and 65 , total score average 71 and there is significant difference) High HDI area (Palembang, Surakarta, Batam and Bandung) is better prepared because it has Local Regulation and Local Head of Government Regulation for more innovative programs. Furthermore, Surakarta and Bandung have integrated educational programs and activities within their RPJMD, while Palembang and Batam include innovation programs and activities on its local government strategic planning. Meanwhile, among Low HDI Region only West Lombok District included innovation programs and activities on its local government strategic planning, Pesawaran and Bangkalan have not developed regional innovation regulation, although they have some innovative programs in education service and health. This condition shows that innovation is still done partially and has not yet integrated into the local program.

Innovative leadership is highly perceived by both high and low HDI areas (average score 63), however, differential test results show significant differences in innovative leadership preparedness, where leaders in high HDI areas are perceived to be more innovative than low HDI areas, judging by the commitment of regional heads to undertake innovation and local head support for innovative development research and also the involvement of the Research Council to formulate regional development policies. This finding is in line with Fontana's (2011: 45) opinion that innovation requires the leader's role to change the ordinary ways, from setting goals and achievement plans, motivating employees, coordinating and evaluating 


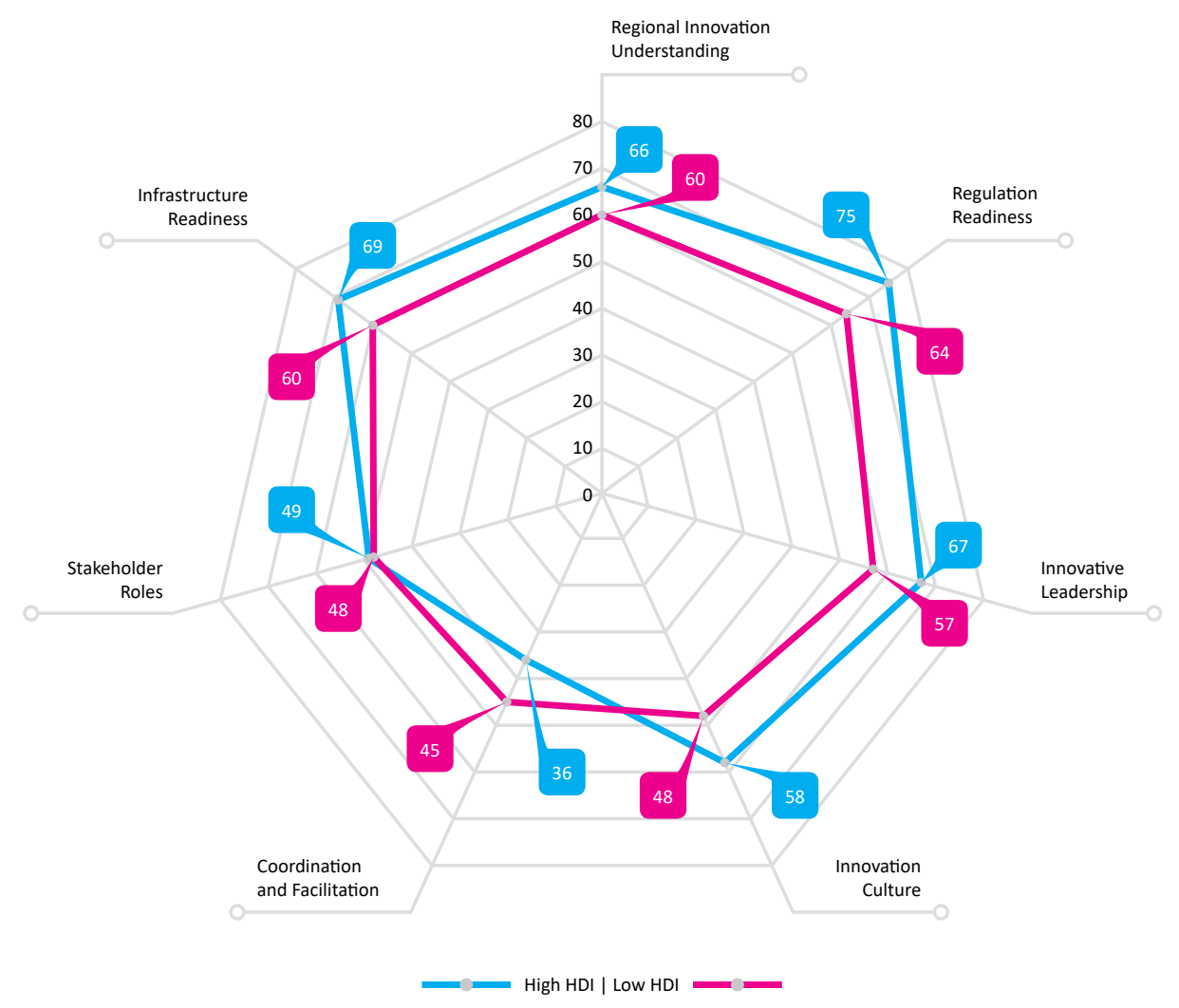

Figure 2. Spiderweb Diagram on the Readiness of Innovation Support Factors in High and Low HDI Areas

programs, accumulating and allocating resources, acquiring and applying knowledge as well as building relationships.

The culture of innovation both in high and low HDI areas are in low category (average score 54). This is indicated by low cultural innovation among local employees in low HDI areas (score 48). The differential test shows that there is a significant difference between cultural innovation readiness for both typologies of the area. In other words, innovation culture has not been established among local workers. This finding is quite alarming for the development of regional innovation. Although the culture of innovation is not the main driver of growth and death of innovation. However, if it remains undeveloped, it would be tough for the local government to create changes. This finding is in line with the LAN study (2013: 16) that encouraging the culture innovation at government sector can be done by creating an innovation culture among employees to be willing to accept, present and apply new ideas and practices to improve performance.

Coordination and facilitation are in a low category (score average 40). Low central government support, coordination intensity and supervision, facilitation of local governments for budgets, capacity building of human resources and technological facilities are contributing factors to the weakness of this aspect. It is quite an interesting phenomenon; it turns out that low HDI area scores outperformed areas with high HDI. This is somewhat different from existing patterns where coordination and facilitation are higher in developed regions. There is also a significant difference in the level of coordination and facilitation of innovation between the two types of regions, where low HDI areas facilitate innovation in the form of capacity building and encourage budget certainty. Capacity building is done through the facilitation of learning, encouraging local initiatives, funding innovative programs, or providing special funds.

The next factor is stakeholder cooperation that has a low score (score average 48). This factor includes cooperation between a local government with academics, business actor and society. There is no difference result between high and low HDI areas in terms of stakeholder cooperation. This is due to the lack of knowledge sharing among stakeholders, such as university research, inadequate support for innovative programs for services, empowerment and enhancement of competitiveness including the inconsistent supply of innovations from the government to communities and business actors. This finding is important to be looked more deeply, because cooperation between stakeholders is very influential on the development of regional innovation, as Etzkowitz \& Leydesdorff (2000) said that the interaction between universities 
(academics), industry and government is the key to create conducive environment for the development of innovation and local economic development.

Lastly, infrastructure readiness perceived by high HDI and low HDI areas is in high category (score average 65). There is a significant difference between the availability of innovative infrastructure facilities between local governments with high and low HDI where high HDI areas tend to be better at preparing infrastructure compared to areas with low HDI. Saparita et al. (2015) argues that the implementation of regional innovation to improve the living standards of agricultural communities in some areas in NTT is constrained by unavailability infrastructure; therefore, the role of central and local government to provide infrastructure is expected to overcome these obstacles. For developing regions with low HDI it is important to prepare regional infrastructures such as transportation facilities, financial institutions, markets, communication media and information facilities.

\section{B. The Relation Between Regional Innovation Supporting Factors}

Further search can also be seen on how the linear correlation between the factors presented in Table 7 which is not an indication of causality, but it may help in understanding the pattern of relationships. Based on the correlation test results there is a very real understanding perception of regional innovation with regulatory readiness, innovation culture, coordination and cooperation among stakeholders. Furthermore, there is a very

Table 7.

Relation of Regional Innovation Supporting Factor

\begin{tabular}{|c|c|c|c|c|c|c|c|}
\hline & & $\begin{array}{c}\text { Regulation } \\
\text { Readiness } \\
\text { X2 }\end{array}$ & $\begin{array}{l}\text { Leadership } \\
\text { X3 }\end{array}$ & $\begin{array}{c}\text { Innovation } \\
\text { Culture } \\
\text { X4 }\end{array}$ & $\begin{array}{c}\text { Coordination } \\
\times 5\end{array}$ & $\begin{array}{c}\text { Cooperation } \\
\text { X6 }\end{array}$ & $\begin{array}{l}\text { Infrastructures } \\
\text { X7 }\end{array}$ \\
\hline \multirow{3}{*}{$\begin{array}{l}\text { Perception } \\
\text { X1 }\end{array}$} & Pearson & $.628^{* *}$ & .273 & $.732 * *$ & $.630 * *$ & $.636^{* *}$ & .213 \\
\hline & Correlation & & & & & & \\
\hline & Sig. (2-tailed) & .000 & .098 & .000 & .000 & .000 & .200 \\
\hline \multirow{3}{*}{$\begin{array}{l}\text { Regulation } \\
\text { Readiness } \\
X 2\end{array}$} & Pearson & 1 & $.435^{* *}$ & $.520 * *$ & $.383^{*}$ & $.565 * *$ & $.475^{* *}$ \\
\hline & Correlation & & & & & & \\
\hline & Sig. (2-tailed) & & .006 & .001 & .018 & .000 & .003 \\
\hline \multirow{3}{*}{$\begin{array}{l}\text { Leadership } \\
\text { X3 }\end{array}$} & Pearson & $.435^{* *}$ & 1 & .305 & .086 & .305 & $.471 * *$ \\
\hline & Correlation & & & & & & \\
\hline & Sig. (2-tailed) & .006 & & .063 & .606 & .063 & .003 \\
\hline \multirow{3}{*}{$\begin{array}{l}\text { Innovation } \\
\text { Culture } \\
\text { X4 }\end{array}$} & Pearson & $.520 * *$ & .305 & 1 & $.398^{*}$ & $.528 * *$ & .213 \\
\hline & Correlation & & & & & & \\
\hline & Sig. (2-tailed) & .001 & .063 & & .013 & .001 & .199 \\
\hline \multirow{3}{*}{$\begin{array}{l}\text { Coordination } \\
\times 5\end{array}$} & Pearson & $.383^{*}$ & .086 & $.398^{*}$ & 1 & $.427 * *$ & .068 \\
\hline & Correlation & & & & & & \\
\hline & Sig. (2-tailed) & .018 & .606 & .013 & & .007 & .687 \\
\hline \multirow{3}{*}{$\begin{array}{l}\text { Cooperation } \\
\text { X6 }\end{array}$} & Pearson & $.565^{* *}$ & .305 & $.528 * *$ & $.427^{* *}$ & 1 & .273 \\
\hline & Correlation & & & & & & \\
\hline & Sig. (2-tailed) & .000 & .063 & .001 & .007 & & .097 \\
\hline \multirow{3}{*}{$\begin{array}{l}\text { Infrastructures } \\
\text { X7 }\end{array}$} & Pearson & $.475^{* *}$ & $.471^{* *}$ & .213 & .068 & .273 & 1 \\
\hline & Correlation & & & & & & \\
\hline & Sig. (2-tailed) & .003 & .003 & .199 & .687 & .097 & \\
\hline
\end{tabular}

** Correlation is significant at the 0.01 level (2-tailed).

* Correlation is significant at the 0.05 level (2-tailed). 


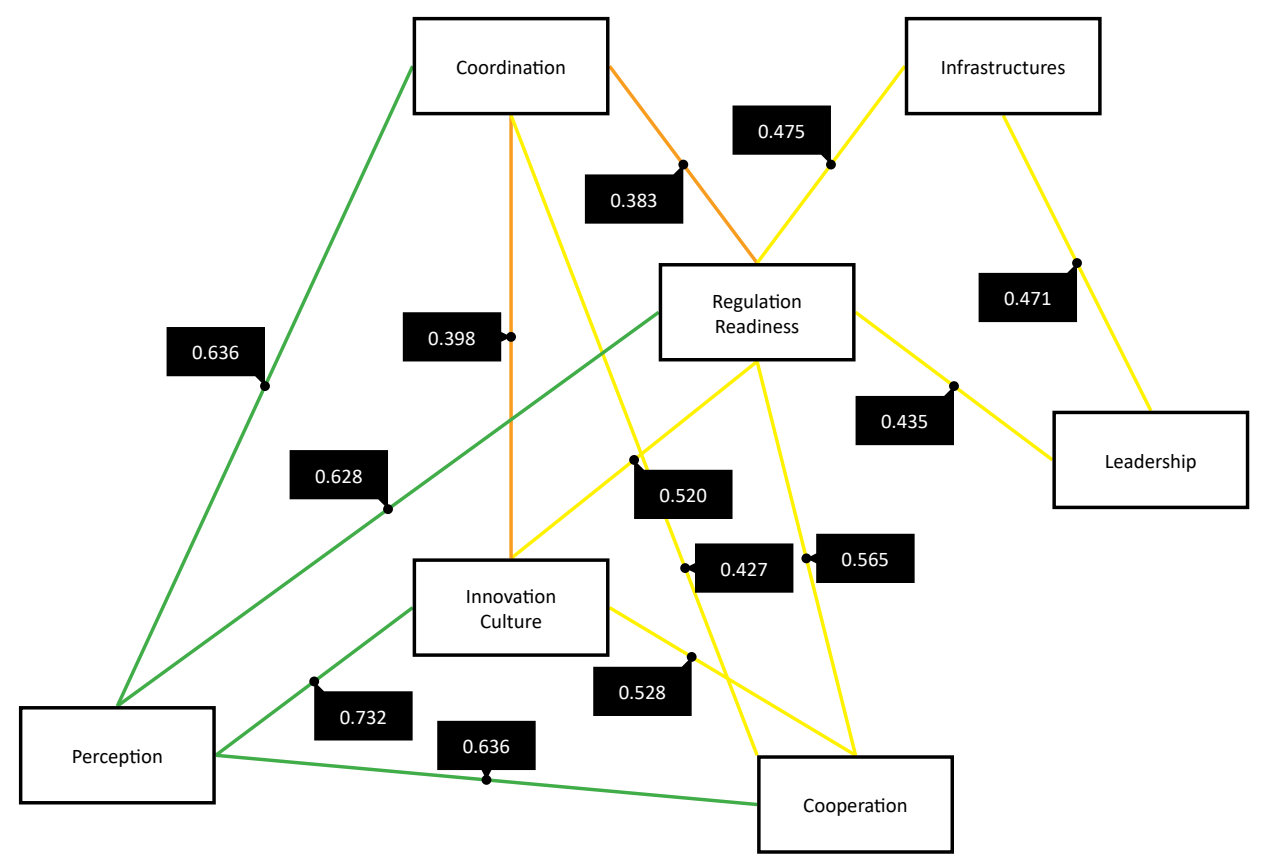

Notes:

very significant relation (very important)

very significant relation (important)

significant relation (rather important)

real relationship between innovation culture and regulatory readiness. This means, if the culture of innovation is well built there can be a possibility that the regulation will be better prepared. Similarly, there is also a very real relationship between innovation culture and cooperation among stakeholders. In other words, it can be concluded, the higher the culture of innovation, the tendency of cooperation among stakeholders will also increase. There is a positive relationship pattern of innovation culture and facilitation/coordination between government and among stakeholders.

The relationship model (Figure 2) shows that understanding of innovation has a very significant (very important) correlation with the culture of innovation, facilitation and coordination, stakeholder cooperation and regulatory readiness. This means that the better perceptions of employees' understanding of innovation the culture of innovation, facilitation, and coordination, stakeholder cooperation and regulation readiness for the development of regional innovation will also improve.

Significant (important) correlations are shown by the aspects of stakeholder cooperation with regulation readiness, innovation culture, facilitation and coordination. This means stakeholder cooperation is closely related to regulation readiness, facilitation and coordination and innovation culture. The significant correlation also shows an important relationship between the readiness of innovation regulation with innovation culture and stakeholder cooperation. A significant (important) relationship is also demonstrated between leadership with regulation readiness and regional innovation supporting infrastructure. It means innovative leadership is related to the preparation of regulations and infrastructure support facilities of regional innovation.

However, these findings reveal that leadership has not been oriented towards the creation of innovation culture among employees, as evidenced by the score of innovation cultures in high HDI and low HDI areas that fall in score 49 to 52 ranges, indicating a less developed innovation culture among employees. The low culture of innovation is due to the risk factors that often hinder the creativity of the government to innovate, although the efforts to protect the employee that innovates from lawsuit law has been set in Article 189 of Law 23 of 2014.

The role of a leader is crucial to building an innovation culture. Leaders have the right to intervene and change the usual ways of doing, from setting goals and planning, motivating, coordinating and evaluating programs and activities, accumulating and allocating resources, acquiring and applying knowledge, building and nurturing relationships with stakeholders, and motivate by giving awards to spur employee creativity.

Furthermore, the significant relation (rather important) as shown by the orange line shows the relationship between facilitation and coordination with regulation readiness and innovation culture. It means facilitation and coordination require the 
support of regulation readiness and preparedness of innovation culture within the Local Government. Support of regulation readiness and innovation policies has not optimally encouraged innovation, especially in low HDI areas. Innovation is done in the Local Government Organization (OPD), based on the decision of the Head of Local Government Organization and is included in Strategic Work Plan. It is less effective to encourage the realization of regional development goals holistically. Innovation is still partially done, unintegrated and only limited to improve Local Government Organization performance. Local innovations should be integrated, included in the RPJMD and set out in the local regulation to encourage the realization of regional development objectives in all aspects. This finding is in line with the study of Handayani et al. (2012) who found that there has been no local regulation for innovation development in the cities, even though the steps or innovation-based work programs have been performed in the Department of Marine and Fisheries, Agriculture Agency, Education Office, and others.

The highest correlation lies in the relationship between innovation understanding and innovative culture. This condition reflects that innovation culture factor becomes an important element to evaluate the understanding of regional innovation among the Local Government employees. This means that by increasing the understanding of innovation, the culture of innovation will also increase. This finding is in line with the view of Lembaga Administrasi Negara (2016) that the culture of innovation in the government sector can increase by changing the mindset through learning within the organization. Employees are educated to be open and free to accept and express new ideas. There are no structural, psychological, and cultural barriers to everyone regardless of his or her background for speaking and doing innovative steps for better change in his or her organization.

\section{ConClusion}

According to the results of the analysis, it was concluded that the regional readiness in implementing innovations on the following factors: the employee's understanding of regional innovation, regulation readiness, emerging innovative leadership, the culture of innovation and adequate innovative support facilities has evolved, despite it still needs strengthening steps support from local governments. On the other hand, there is potential for unpreparedness at lack of coordination and facilitation as well as the lack stakeholder roles (universities, business actors, and communities) who partner with government to develop local innovation.
There is a difference in the readiness of regional innovation between high and low HDI areas, where the readiness of supporting factors is better at high HDI areas than low HDI areas, including regulation readiness, innovation culture, stakeholder cooperation and innovation supporting infrastructure.

The relationship between the supporting factors of regional innovation implementation can see from the three categories of relationships that are divided into the degree of relationship, those are: very important, important and rather important. First, the very important relationship between the factors of understanding innovation with innovation culture, facilitation and coordination, stakeholder cooperation and regulation readiness. Secondly, the important relationship between stakeholder cooperation factors with regulation readiness, innovation culture, facilitation and coordination. The important link between innovation regulation readiness and innovation culture and stakeholder cooperation and also an important link between leadership factors and regulation readiness and infrastructure innovation supporting tools. Lastly, the rather important relationship between facilitation and coordination of regulation readiness and innovation culture.

Based on the findings above, strategic issues in regional readiness in implementing regional innovation consist of three things: first, innovative understanding can be used for innovation, especially to develop and improve efficiency and coordination. Second, the existence of innovative leader is crucial to creating innovation cultures among employees and it needs to be institutionalized in the regulation. Third, by analyzing the difference of regional readiness to implement innovation based on HDI, it is concluded that the increase of HDI as a required conducive pre-condition for the development of regional innovation is essential.

This review recommends two things. First, the Central and Local Governments need to address the crucial problem of innovation barriers. This can be done through strengthening inter-agency coordination and facilitation of local innovation. Some of the programs that can be developed are building a multi-stakeholder working group involving Central Government, local government, universities, R \& D institutions, business and community. Furthermore, the implementation of the joint secretariat for the development of regional innovations involving central government and local government elements followed by innovation understanding improvement programs, preparation and harmonization of innovation regulations, fostering innovative leadership, stimulating innovation culture and preparation of infrastructures. 
Second, the government/local governments need to pay attention and interventions to improve innovation support factors in low HDI areas so that the gap or innovation gap between regions is not getting higher. This can be done in the form of improving regional understanding about the importance of innovation development for regional progress, facilitating to structuring legislation and innovation support policies, facilitating collaboration between $\mathrm{R}$ \& $\mathrm{D}$ institutions and universities for the development of innovations that can be utilized by the region, facilitating cooperation between government agencies, research and development, private and community and providing infrastructure to support development of regional innovation.

Proposed strategies and policy directions for regional innovation development is divided into core strategies and supporting strategies. The core strategies are: Partnership programs development between Government and Local Gocernment to enhance local innovation capacity through consultation, training and technical assistance for more innovative services; communication networks strengthening activities among Local Government; comparative study activities, conferences and workshops; Publication, socialization and institutionalization of local innovation development thinking for the stakeholders; the preparation and creation of innovation supporting policies and regulations, including regulations on the legality of copyright; Capacity building of universities through budgeting support for regional innovation research on APBD; Replication of regional innovation; Development of data base and data communications of regional innovation in the form of internet based application on regional innovation data base, creating communication network between regional innovation databases at central, provincial, regency/city government, government and private $\mathrm{R}$ \& D institute and also society.

Meanwhile, supporting strategies consist of: stakeholder collaboration in the development of local innovations involving local governments, universities and R \& D institutions, businesses and communities through activities such as establishment of interparty communication forums involving government, private and community elements; collective labor agreements between government, private and community in the development of regional innovation; support for the provision of soft loans for local innovation development and assistance in the preparation of regional innovation development roadmap.

The direction of regional innovation development policy consists of strengthening partnerships among stakeholders; Strengthening understanding and deepening of regional innovation culture; Acceleration of regulations composing process and supporting regulation of regional innovations development including regulations for innovative leadership protection that are operationalized in each local head regulation and regional regulation; Strengthening inter-institutional coordination and facilitation of regional innovation; Capacity building of research and development institute for regional innovation support; Provision of facilities and infrastructure to support and optimize the existing facilities.

\section{ACKNOWLEDGEMENT}

The author would like to thank the Head of Research and Development Agency of the Ministry of Home Affairs, Mr. Drs. Dodi Riyadmadji, MM who gave the opportunity and support for the implementation of this study. We also express our gratitude to the resource persons Mr. Maxensius Tri Sambodo, SE, MIDEC and Dr. Ivanovich Agusta as the experts who guide and direct the author so this study can be completed. And to all parties who have helped in the collection of data, both primary and secondary data.

\section{REFERENCES}

Ancok, D. (2012). Psikologi Kepemimpinan \& Inovasi. Jakarta: Erlangga.

Carayannis, E. G., Barth, T. D., \& Campbell, D. F. (2012). The Quintuple Helix innovation model: global warming as a challenge and driver for innovation. Journal of Innovation and Entrepreneurship, 1(1), 1-12. http://doi. org/10.1186/2192-5372-1-2

Dell'Anno, D., \& del Giudice, M. (2015). Absorptive and desorptive capacity of actors within university-industry relations: does technology transfer matter? Journal of Innovation and Entrepreneurship, 4(1), $13 . \quad$ http://doi. org/10.1186/s13731-015-0028-2

Dwiyanto, A. (2015). Reformasi Birokrasi Kontekstual. Yogyakarta: Gadjah Mada University Press.

Edquist, C. (2001). The Systems of Innovation Approach and Innovation Policy: An account of the state of the art. In DRUID Conference, Aalborg. Aalborg.

Edquist, C., \& Hommen, L. (Eds.). (2008). Small Country Innovation Systems: Globalization, Change and Policy in Asia and Europe. Cheltenham, UK: Edward Elgar. http://doi. org/10.4337/9781847209993

Etzkowitz, H., \& Leydesdorff, L. (2000). The dynamics of innovation: from National Systems and "Mode 2" to a Triple Helix of university-industry-government relations. Research Policy, 29(2), 109-123. http://doi. org/10.1016/S0048-7333(99)00055-4 
Etzkowitz, H., \& Ranga, M. (2010). A Triple Helix System for Knowledge-based Regional Development : From "Spheres" to "Spaces." In VIII Triple Helix Conference (pp. 1-29). Madrid.

European Commission. (2013). Powering European Public Sector Innovation: Towards A New Architecture. Report of the Expert Group on Public Sector Innovation. http://doi. org/10.2777/51054

Handayani, W., Setyono, J. S., Sophianingrum, M., \& Kusharsanto, Z. S. (2012). Kajian Pengembangan Sistem Inovasi Daerah (SIDa) Kota Semarang. Riptek, 6(2), 1-16.

Handayani, W., Sophianingrum, M., \& Nutriandini, U. (2013). Kajian Roadmap Pengembangan Sistem Inovasi Daerah (SIDa) Kota Semarang. Riptek, 7(2), 97-108.

Imanudin, M. (2016). Penilaian Inovasi Pelayanan Publik. In Seminar Nasional Inovasi Daerah BPP Kemendagri. Jakarta, Indonesia.

James, T. (Ed.). (2010). Enhancing Innovation in South Africa: The COFISA Experience. Pretoria: Department of Science and Technology, Government of South Africa.

Kimatu, J. N. (2016). Evolution of strategic interactions from the triple to quad helix innovation models for sustainable development in the era of globalization. Journal of Innovation and Entrepreneurship, 5(1), 16. http://doi. org/10.1186/s13731-016-0044-x

Lembaga Administrasi Negara. (2016). Penilaian Inovasi di Sektor Publik. In Seminar Kajian Strategi Penilaian Inovasi Daerah BPP Kemendagri. Jakarta, Indonesia.

Mulgan, G., \& Albury, D. (2003, October). Innovation in the public sector. London, UK.

Natalisa, D. (2016). Inovasi Pelayanan Publik untuk Peningkatan Kualitas Pelayanan Publik. In Seminar Nasional Inovasi Daerah BPP Kemendagri. Jakarta.

Pramusinto, A. (2016). Mendorong Perubahan dari Luar: Ke Arah Birokrasi Indonesia yang Demokratis dan Melayani. In Pidato Pengukuhan Jabatan Guru Besar Ilmu Administrasi Negara FISIP UGM. Yogyakarta.

Purnomo, D., Pujianto, T., \& Efendi, N. (2015). Unpad - Ibu Popon Collaboration; A Best Practice in Sustainable Assistance Model for Social Entrepreneurship in Agro-industrial Based SME's. Agriculture and Agricultural Science Procedia, 3, 206-210. http://doi. org/10.1016/j.aaspro.2015.01.040

Rogers, E. M. (2003). Diffusion of Innovations (5th ed.). New York: The Free Press.

Saparita, R., Dyah, S., Abbas, A., \& Hidajat, E. W. (2015). Membangun Sistem Inovasi untuk Kesejahteraan Masyarakat. Jakarta: LIPI Press.

Sumardjo. (1999). Transformasi Model Penyuluhan Pertanian Menuju Pengembangan Kemandirian Petani (Kasus di Propinsi Jawa Barat). Bogor Agricultural University. Retrieved from http://repository.ipb.ac.id/ handle/123456789/42580

Sumarto, H. S. (2009). Inovasi, partisipasi dan good governance: 20 prakarsa inovatif dan partisipatif di Indonesia. Jakarta: Yayasan Obor Indonesia.

Taufik, T. A. (2005). Pengembangan Sistem Inovasi Daerah: Perspektif Kebijakan. Jakarta: BPPT.

The World Bank. (2007). Enhancing Agricultural Innovation: How to Go Beyond the Strengthening of Research Systems. Washington, DC: The World Bank. http://doi.org/10.1596/978-08213-6741-4

United Nations Conference on Trade and Development. (2010). Enhancing food security in Africa through science, technology and innovation. Technology and Innovation Report 2010. New York and Geneva: United Nations Publication. Retrieved from http://unctad. org/en/Docs/tir2009_en.pdf 